\title{
Geothermal Energy Utilization in the United States of America
}

\author{
J. Lund \\ National Renewable Energy Laboratory, Golden, Colorado, USA \\ *Tel: +1 541-891-2977, Fax: +1 541-885-1320,E-mail: john.lund@nrel.com
}

\begin{abstract}
Geothermal energy is used for electric power generation and direct utilization in the United States. The present installed capacity (gross) for electric power generation is 3,087 MWe with about 2,024 MWe net delivering power to the gird producing approximately 16,600 GWh per year for a 94\% net capacity factor. Geothermal electric power plants are located in Alaska, California, Hawaii, Idaho, Nevada, New Mexico, Oregon, Utah, Wyoming. The direct utilization of geothermal energy including the heating of pools and spas, greenhouses and aquaculture facilities, space heating and district heating, snow melting, agricultural drying, industrial applications and ground-source heat pumps. The installed capacity is approximately 12,610 MWt and the annual energy use is about 56,550 $\mathrm{TJ}$ or 15,700 GWh. The largest application is ground-source (geothermal) heat pumps (84\% of the energy use). The largest direct-use (excluding geothermal heat pumps) is fish farming (34\%), spa and swimming pool heating (28\%), and space and district heating (23\%). The energy savings from all geothermal use is about 48.5 million barrels ( 7.3 million tonnes) of equivalent fuel oil per year and reduces air pollution by about 6.65 million tonnes of carbon annually (compared to fuel oil).
\end{abstract}

Keywords: geothermal energy, electric power, direct-use, geothermal heat pumps

\section{Introduction}

Geothermal resources capable of supporting electrical generation and/or direct use projects are found primarily in the Western United States, where most of the recent volcanic and mountain building activity have occurred. The San Andreas fault running through California from the Imperial Valley to the San Francisco area, and the subduction zone off coast of northern California, Oregon and Washington along with Cascade volcanism are the source of much of the geothermal activity in the United States. However, geothermal (ground-source) heat pumps extend the utilization to all 50 states. The total identified potential for electrical production is estimated at $21,000 \mathrm{MWe}$ (above $150^{\circ} \mathrm{C}$ ) and $42 \mathrm{EJ}$ (between $90^{\circ}$ and $150^{\circ} \mathrm{C}$ ) of beneficial heat [1], and a recent estimate by the U.S. Geological Survey estimates a mean probability of electrical power generation from identified geothermal resources in12 western states during the next 30 years of 8,866 MWe, which would nearly triple the existing electrical capacity. Currently, the geothermal electrical generation installed capacity is 3,048 MWe (gross), 2,024 MWe (net), and the annual energy produced is 16,603 GWh/yr.

Geothermal direct-use is currently estimated at 9,152 TJ/yr (2,542 GWh/yr) with an installed capacity of $611 \mathrm{MWt}$. Geothermal heat pumps contribute 47,400 TJ/yr (13,167 GWh/yr) with an installed capacity of 12,000 MWt. The total of all direct utilization in the United States is 56,552 TJ/yr (15,709 GWh/yr) with an installed capacity of 12,611 MWt. A total of 20 new direct-use projects have come on line over the past five years, but this increase has been partially offset with closing of one agricultural drying plant and two small district heating projects. Geothermal heat pumps have seen the largest gain, growing at slightly over 10 percent a years with installed units.

This paper is based on material present at the World Geothermal Congress 2010, Bali, Indonesia [2]. 


\subsection{Summary of Electric Power Generation}

Even though the United States is the world leader in geothermal electric power generation, geothermal energy remains a small contributor to the electric power capacity and generation in the United States. In 2009, geothermal plants constituted about 0.27 percent of the total operable power capacity, and those plants contributed an estimated 0.48 percent of the total generation.

Since 2005 gross geothermal electrical production capacity has increased in the United States by approximately 500 MWe to a total an installed capacity of 3047.7 MWe and a net running capacity of 2,023.5 MWe due to derating of plants in The Geysers, producing 16,603.4 $\mathrm{GWh} / \mathrm{yr}$ for a gross capacity factor of 0.62 and a net of 0.94 . The low net value is due to plants, especially in The Geysers, operating in a load following mode rather than in a base load mode and due to a reduction in pressure and output of the steam field. The geothermal electric power generation accounted for $4 \%$ of the total renewable based electricity consumption in the United States. On a state level, geothermal electric generation is a major player in California and Nevada. The period 1990-2004 also saw a reduction at The Geysers geothermal field in northern California from 1,875 to around 1,529 MWe installed capacity and 945 MWe running capacity. Today, the installed capacity is 1584 MWe and 844 MWe running capacity. This was due to the closing of four units and a reduction in the steam availability. Some capacity has been restored due to the construction of two effluent pipelines, one from Clear Lake and the other from Santa Rosa, that brings about 72,000 tonnes of water per day (19 million gallons/day) to The Geysers for injection. This has restored an estimated 200 MWe of capacity to the field.

\subsection{Summary of Direct Utilization}

Direct-use, other than geothermal heat pumps, has remained static with increases being balanced by closing of some facilities. The main increases has been in expanding the Boise City District Heating System from 48 to 58 buildings; adding additional wells for space heating in Klamath Falls; expanding the snow melting system on the Oregon Institute of Technology campus from $316 \mathrm{~m}^{2}$ to $3,753 \mathrm{~m}^{2}$, increasing the amount of aquaculture product being produced, mainly Tilapia; starting two biodiesel plants; adding an absorption chiller for keeping the Ice Museum at Chena Hot Springs in Alaska intact during the summer months, and adding additional space heating to the Peppermill Casino in Reno. Losses have been the closing of the district heating systems at the California Correctional Center (now using natural gas) and the New Mexico University heating system (due to difficulty with maintenance), and the closing of the Empire onion dehydration plant (due to competition with imported garlic from China) near Gerlach, Nevada.

Geothermal heat pumps have seen the largest growth, increasing over the past five years from an estimated 600,000 to $1,000,000$ equivalent $12 \mathrm{~kW}$ installed units. The estimated installation rate is from 100,000 to 120,000 units per year, or about a 12 to 13 percent annual growth, with most of the growth taking place in the mid-western and eastern states. A few states have tax rebate programs for geothermal heat pumps, and Congress has established a tax credit of $30 \%$ of costs up to $\$ 1,500$ for installations. Otherwise, there is little support for implementing direct-use projects.

\subsection{Enhanced (Engineered) Geothermal Systems}

Enhanced (Engineered) Geothermal Systems (EGS) is the current R\&D interest of the U.S. Department of Energy, Office of Geothermal Technologies as part of a revived national geothermal program. EGS includes the earlier hot dry rock technology, but now includes any 
other method in which to improve geothermal reservoir performance. EGS is associated with both magmatic and high heat producing crustal sources of geothermal energy commonly at depths of about 4 to $5 \mathrm{~km}$ to reach $200^{\circ} \mathrm{C}$, but also having applications with normal gradient resources. However, EGC projects are currently at an early experimental demonstration stage. Several technological challenges need to be met for widespread efficient use of EGS. The key technical and economic changes for EGS over the next two decades will be to achieve economic stimulation of multiple reservoirs with sufficient volumes to sustain long term production, with low flow impedance, limited short-circuiting fractures and manageable water loss [3].

\section{Production of Electricity}

The total geothermal electrical installed capacity at the beginning of 2010 was 3,048 MWe producing 16,603 GWh/yr from a running capacity of 2,024MWe. A total of about $514 \mathrm{MWe}$ has been installed in the last five years, amounting to a 20 percent increase or 3.7 percent annual increase.

\subsection{Installed and Future Capacity Update}

\subsubsection{Alaska}

Alaska's first geothermal power plant came online in 2006 in Chena Hot Springs. It is a small organic Rankine cycle (ORC) unit ( $250 \mathrm{~kW}$ gross) and produces electricity from the area's low temperature $\left(74^{\circ} \mathrm{C}\right)$ geothermal resource. Since coming online the power plant has added another $250 \mathrm{~kW}$ unit as well as a $280 \mathrm{~kW}$ unit, bringing total production capacity to $730 \mathrm{~kW}$ (gross).

Alaska currently has 70 to 115 MW of planned geothermal production coming down the pipeline. Of projects with potential to come online, the Southwest Alaska Regional Geothermal Energy Project $25 \mathrm{MWe}$, is in an exploratory drilling and resource confirmation phase. Other notable projects are Tongass (20 MWe), Unalaska (10-50 MWe), Pilgrim Hot Springs (10 MWe), and Chena Hot Springs II (5-10 MWe).

\subsubsection{California}

Current geothermal electricity grossproduction capacity in California is approximately 2497 MWe (1,627 MWe net). In 2010, 4.5\% of California's electricity generation came from geothermal power plants, amounting to a net total of 13,605 GWh. The 50 MW North Brawley facility is the state's most recent geothermal power plant addition. Generally, geothermal power generation remains concentrated in California with the majority of production occurring at The Geysers in the north and Imperial Valley in the south.

California has approximately 1,555 - 19,39 MWe of planned geothermal resource production in various stages of development. Production drilling and facility construction are underway at Western GeoPower Corp.'s Unit 1 (35 MWe) at the Geysers as well as CHAR, LLC's Hudson Ranch I (49.9 MWe). Final permitting and PPA's are being secured for Ormat Technologies East Brawley project (30 MWe), Calpine Corporations Buckeye-North Geysers (30 MWe) and Wildhorse-North Geysers (30 MWe) projects, and CalEnergy's Black Rock 1, 2, and 3 units (53 MWe each).

\subsubsection{Hawaii}

There is only one geothermal power plant in all of Hawaii. Located on the big island, the Puna Geothermal Venture facility has a 35 MWe nameplate capacity and delivers 25-35 MWe of energy on a continuous basis and supplies $20 \%$ of the electricity needs of the big 
island. Ormat is in the process of securing a PPA and final permitting for an 8 MWe expansion of its Puna project. The 10 units consist of a flash steam plant with a binary bottoming cycle plant.

\subsubsection{Idaho}

Idaho's first geothermal power plant, Raft River, came online in January 2008. Raft River is a binary plant that uses a $150^{\circ} \mathrm{C}$ resource and has a nameplate production capacity of 15.8 MWe. Current net production output is between 10.5 and 11.5 MWe. US Geothermal is securing a PPA and final permitting for a 13 - 26 MWe expansion of the Raft River plant.

Another geothermal company, Idatherm, is developing a number of projects throughout Idaho. Idatherm has begun exploratory drilling and resource confirmation operations for its Willow Springs project (100 MWe). It is also planning to develop its China Cap (100 MWe), Preston Area Project (50 MWe), and Sulfur Springs (25 - $50 \mathrm{MWe}$ ) resources but is still in the process of conducting initial exploratory drilling and securing rights to resource. Total potential geothermal production for Idaho is 238 to 326 MWe.

\subsubsection{Nevada}

In 2008 Nevada had 18 geothermal power plants with a total nameplate capacity of 333 MWe and with a total gross output of 10,791 MWh/yr. In 2009 Nevada increased its installed geothermal capacity with the addition of the Stillwater (ENEL, 47.3 MWe), Salt Wells (ENEL, 18.6 MWe), and the Blue Mountain "Faulkner 1" (Nevada Geothermal Power, 49.5 MWe) power plants. Currently Nevada has more developing projects than any other state and it is expected that gross capacity will increase significantly in the future. The following companies have begun production drilling and facility construction at various project sites: Vulcan Power (Salt Wells, 175 - 245 MWe), Presco Energy (Rye Patch, 13 MWe), and US Geothermal (San Emidio "Repower” Project, 8.4 MWe), Ormat (Jersey Valley, 18 - 30 MWe). Many other companies are in the process of securing PPA's and final permitting for a number of projects and other companies are in the early exploratory stages of developing numerous geothermal resources. Nevada currently has 1,776 to 3,323 MW of geothermal capacity in development.

\subsubsection{New Mexico}

In July 2008, a 0.24 MWe pilot installation project came online at Burgetts Greenhouses near Animas. The pilot installation is part of a larger project known as Lightning Dock that aims to bring a 20 MWe capacity geothermal power plant online in 2011.

\subsubsection{Oregon}

While there is only one small unit producing geothermal electricity, significant developments are forthcoming. The Oregon Institute of Technology (OIT) has installed a $280 \mathrm{kWe}$ (gross) binary units and is currently producing power for use on campus - the first campus in the world to generate its own power from a resource directly under campus. OIT has also completed production drilling of a 1,600-m deep well and will install a 1.2 MWe binary power unit by 2012 using the $93^{\circ} \mathrm{C}$ resource at $158 \mathrm{~L} / \mathrm{s}$. Davenport Power, U.S. Renewables Group, and Riverstone are securing a PPA and final permitting for their 120 MWe Newberry Geothermal project as is Nevada Geothermal Power for its 40 - 60 MWe Crump Geyser project. U.S. Geothermal, Inc. successfully completed the drilling of its second full sized production well at Neil Hot Springs (20 - 26 MWe) in October 2009. Overall there are 317 to 368 MWe of potential geothermal power capacity in planning in Oregon. 


\subsubsection{Utah}

Currently, Utah has three power plants online. Unit 1 of the Blundell Plant has a gross capacity of 25 MWe and Unit 2 has a capacity of 11 MWe. Utah's third power plant came online in December 2008 and was the first commercial power plant in the state in more than 20 years. The Thermo Hot Springs power plant, a Raser Techologies operation, came online in 2009 and has a gross capacity of 14 MWe and is expected to generate with a net capacity of approximately 10 MWe. Shoshone Renaissance Geothermal Project. ENEL North America has begun exploratory drilling and resource confirmation operations at its Cove Fort (69 MWe) project site. Other companies have potential geothermal sites that are in the early stages of planning/development and overall Utah has 272 to 332 MWe of planned geothermal capacity for future production.

\subsubsection{Wyoming}

In August 2008, a 250 kWe Ormat organic Rankine cycle (ORC) power unit was installed at Rocky Mountain Oil Test Site (RMOTC) and a month later it began operating. As of January 2009, the unit had produced more than $485 \mathrm{MWh}$ of power from 413,000 tonnes of hot water annually. The demonstration project is still in operation, and a United Technology Corporation $280 \mathrm{kWe}$ plant is scheduled for operation in 2011. During operation these plants will be an evaluation of how to reduce fluctuations of power and to generate more than 250 kWe.

\section{Geothermal Direct Utilization}

\subsection{Background}

Geothermal energy is estimated to currently supply for direct heat uses and geothermal (ground-source) heat pumps 56,552 $\mathrm{TJ} / \mathrm{yr}(15,709 \mathrm{GWh} / \mathrm{yr})$ of heat energy in the United States. The corresponding installed capacity is 12,611 MWt. Of these values, direct-use is $9152 \mathrm{TJ} / \mathrm{yr}(2,542 \mathrm{GWh} / \mathrm{yr})$ and $611 \mathrm{MWt}$, and geothermal heat pumps the remainder.

Most of the direct use applications have remained constant or decreased slightly over the past five years; however geothermal heat pumps have increased significantly. A total of 20 new projects have come on line in the past five years.

\subsection{Space Heating}

Space heating of individual buildings (estimated at over 2,000 in 17 states) is mainly concentrated in Klamath Falls, Oregon where about 600 shallow wells have been drilled to heat homes, apartment houses and businesses. Most of these wells use downhole heat exchangers to supply heat to the buildings, thus, conserving the geothermal water [4]. A similar use of downhole heat exchangers is found in the Moana area of Reno, Nevada [5]. Installed capacity is $140 \mathrm{MWt}$ and annual energy use is $1361 \mathrm{TJ}$.

\subsection{District Heating}

There are 20 geothermal district-heating systems in the United States, most being limited to a few buildings. The newest is a small project in northern California [6]. In this rural community of Canby, geothermal heat is used for heating buildings, a greenhouse, and most recently driers and washers in a laundry. The city system in Boise, Idaho has added 10 buildings to their system and will be extended to Boise State University next year. Klamath Falls system has expanded by adding a brewery and an additional greenhouse. Installed capacity is 75 MWt and annual energy use is $773 \mathrm{TJ}$ (215 GWh). 


\subsection{Aquaculture Pond and Raceway Heating}

There are 51 aquaculture sites in 11 states using geothermal energy. The largest concentration of this use is in the Imperial Valley in southern California and operations along the Snake River Plain in southern Idaho. There is a report that some of the facilities in the Imperial Valley have closed, but reliable information is lacking. A large facility at Kelly Hot Springs in northern California has been expanding and now produces slightly over half a million kg of tilapia annually. Two unique aquaculture related projects are in operation in Idaho and Colorado - that of raising alligators [7]. Recent trends in the U.S. aquaculture industry have seen a decline in growth due to saturation of the market and competition from imports. Installed capacity is $142 \mathrm{MWt}$ and annual energy use is $3074 \mathrm{TJ}$ (854 GWh).

\subsection{Greenhouse Heating}

There are 44 greenhouse operations in nine states using geothermal energy. These cover an area of about 45 ha, have an installed heat capacity of $97 \mathrm{MWt}$ and an annual energy use of $800 \mathrm{TJ} / \mathrm{yr}(222 \mathrm{GWh})$. The main products raised are potted plants and cut flowers for local markets. Some tree seedlings and vegetables are also grown in Oregon; however raising vegetable is normally not economically competitive with imports from Central America, unless they are organically grown. One unusual greenhouse product, started recently, is spider mites grown on lima bean plants at Liskey Farms south of Klamath Falls, Oregon. They are grown for their eggs which are then shipped south as feed for predator mites, which in turn are sold to farms to eat spider mites - a complicated process, as the mites and eggs are almost microscopic in size and difficult to see [8]

\subsection{Industrial Applications and Agricultural Drying}

Industrial applications have increased significantly due to the addition of two biodiesel plants (Oregon and Nevada). These plants primarily use geothermal energy for the distillation of waste grease from restaurants, but one also used canola oil. Small industrial uses include clothes driers and washer installed in Canby, California, and a brewery using heat from the Klamath Falls district heating system for brewing beer and heating the building [9]. The main loss is the closing of an onion/garlic dehydration plant at Empire, Nevada due to competition with imported garlic from China. The installed industrial capacity for these two applications is $40 \mathrm{MWt}$ and the annual energy use $519 \mathrm{TJ} / \mathrm{yr}(144 \mathrm{GWh} / \mathrm{yr})$ with nine facilities located in three states.

\subsection{Cooling and Snow Melting}

The two major uses of geothermal energy are for pavement snow melting, on the Oregon Institute of Technology (OIT) campus, and keeping the Aurora Ice Museum frozen yearround at Chena Hot Springs, Alaska. The installed capacity for this application is $4.8 \mathrm{MWt}$ and the annual energy use is $68 \mathrm{TJ} / \mathrm{yr}(19 \mathrm{GWh} / \mathrm{yr})$.

\subsection{Spas and Swimming Pools}

This is one of the more difficult applications to quantify and even to find all the actual sites, as most owners do not know their average and peak flow rates, as well as the inlet and outlet temperatures. There are 242 facilities in 17 states, with an estimated installed capacity of 113 MWt and annual energy use of 2,557 TJ/yr (711 GWh/yr).

\subsection{Geothermal (Ground-Source) Heat Pumps}

The number of installed geothermal heat pumps has steadily increased over the past 15 years with an estimated 100,000 to 120,000 equivalent $12 \mathrm{kWt}$ units installed this past year. 
Present estimates are that there are at least one million units installed, mainly in the midwestern and eastern states. The present estimates are that approximately $70 \%$ of the units are installed in residences and the remaining 30\% in commercial and institutional buildings. Approximately $90 \%$ of the units are closed loop (ground-coupled) and the remaining open loop (water-source). The estimated full load hours in heating mode is 2000/yr, and in cooling mode is 1000/yr. The installation cost is estimated at US\$6,000 per ton (US\$1,715 per $\mathrm{kW}$ ) for residential and US\$7,000 per ton (US\$2,000 per $\mathrm{kW}$ ) for commercial. The units are found in all 50 states and are growing 12 to $13 \%$ a year. It is presently a US\$2 to US\$3 billion annual industry. The current installed capacity is $12,000 \mathrm{MWt}$ and the annual energy use in the heating mode is $47,400 \mathrm{TJ} / \mathrm{yr}(13,168 \mathrm{GWh} / \mathrm{yr})$. The largest installation currently under construction is for Ball State University, Indiana where approximately 4,000 vertical loops are being installed to heat and cool over 40 buildings.

\subsection{Conclusions - Direct-Use}

The growth of direct use over the past five years is all due to the increased use of geothermal heat pumps, as traditional direct-use development has remained flat. Unfortunately, there is little interest for direct-use at the federal level, as their interests are mainly in promoting and developing Enhanced (Engineered) Geothermal Systems (EGS) and co-produced systems using abandoned oil and gas wells. There are few incentives for the traditional direct-use development, but as mentioned earlier, there are tax incentives for geothermal heat pumps at the federal level and in some states such as Oregon. Since, most direct-use projects are small, there are few, if any, developers and/or investors who are interested in supporting these uses.

\section{Energy and Carbon Savings}

In total, the savings from present geothermal energy production in the U.S., both electricity and direct-use amounts to 48.5 million barrels (7.28 million tonnes) of fuel oil equivalent (TOE) per year, and reduces air pollution by 6.65 million tonnes of carbon annually. $\mathrm{CO}_{2}$ reduction is estimated at 18.8 million tonnes.

\section{Comparison to Other Countries}

Based on data from the WGC2010 [10, 11], the following comparisons with the U.S. geothermal data are made:

\subsection{Worldwide Geothermal Electric Power Generation (5 leading countries, except USA)}

$\begin{array}{lccc}\text { Country } & \begin{array}{c}\text { Installed capacity } \\ \text { (MWe) }\end{array} & \begin{array}{c}\text { Running capacity } \\ \text { (MWe) }\end{array} & \begin{array}{c}\text { Annual energy } \\ \text { produced (GWh/yr) }\end{array} \\ \text { Philippines } & 1,904 & 1,774 & 10,311 \\ \text { Indonesia } & 1,197 & 1,197 & 9,600 \\ \text { Mexico } & 958 & 958 & 7,047 \\ \text { Italy } & 843 & 843 & 5,520 \\ \text { New Zealand } & 628 & 628 & 4,055 \\ \text { World (24 countries) } & 10,715 & \text { n/a } & 67,246\end{array}$

\subsection{Worldwide Geothermal Direct Utilization (5 leading countries, (except USA.)}

$\begin{array}{lccc}\text { Country } & \text { Installed capacity } & \text { Annual energy } & \text { Principal use } \\ & (\mathrm{MWt}) & \text { produced (GWh/yr) } & \\ \text { China } & 8,898 & 20,932 & \text { Bathing/district heating }\end{array}$




$\begin{array}{lccc}\text { Sweden } & 4,460 & 12,585 & \text { Geothermal heat pumps } \\ \text { Japan } & 2,100 & 7,139 & \text { Bathing } \\ \text { Turkey } & 2,084 & 10,247 & \text { District heating } \\ \text { Iceland } & 1,826 & 6,768 & \text { District heating } \\ \text { World (78 countries) } & 48,483 & 117,778 & \end{array}$

As can be calculated compared to the worldwide figures, the United States has $28.8 \%$ of the installed capacity, and $24.7 \%$ of the annual energy produced for electricity generation; and $26.0 \%$ of the installed capacity, and $13.3 \%$ of the annual energy use. The low annual energy direct-use percentage for the U.S. is due mainly to the large number of geothermal heat pumps, which have a low capacity factor. In terms of MWe and MWt, the USA is the leader.

\section{References}

[1] L. J. P. Muffler (editor), Assessment of Geothermal Resources in the United States 1978. U. S. Geological Survey Circular 790, U. S. Department of Interior, 1979.

[2] J. Lund, K. Gawell, T. Boyd, D. Jennejohn, The United States of America Country Update 2010, Proceeding World Geothermal Congress 2010, Bali, Indonesia, International Geothermal Association, 2010 (CD-ROM).

[3] J. Tester, B. Anderson, A. Batchelor, D. Blackwell, R. DiPippo, E. Drake (editors), The Future of Geothermal Energy - Impact of Enhanced Geothermal Systems on the United States in the $21^{\text {st }}$ Century, U.S. Department of Energy, 2006, 358 p.

[4] G. Culver, J. Lund, Downhole Heat Exchangers, Geo-Heat Center Quarterly Bulletin 20/3, Oregon Institute of Technology, Klamath Falls, 1999, pp. 1-11.

[5] T. Flynn, Moana Geothermal Area, Reno, NV - 2001 Update, Geo-Heat Center Quarterly Bulletin 22/3, Oregon Institute of Technology, Klamath Falls, 2001, pp. 1-7.

[6] D. Merrick, Adventures in the Life of a Small District Heating Project or The Little Project That Could, Geothermal Resources Council Transactions 26, Davis, CA (CDROM).

[7] T. Clutter, Out of Africa - Aquaculturist Ron Barnes Uses Geothermal Water in Southern Oregon to Rear Tropical Fish from the African Rift Lake, Geo-Heat Center Quarterly Bulletin 23/3, Oregon Institute of Technology, Klamath Falls, 2002, pp. 6-8.

[8] L. Riley, Inside the Greenhouse: Geothermal Energy and Spider Mite Production, GeoHeat Center Quarterly Bulletin 29/3, Oregon Institute of Technology, Klamath Falls, OR, 2010, pp. 15-18.

[9] A. Chiasson, From Creamery to Brewery with Geothermal Energy, Geo-Heat Center Quarterly Bulletin 27/4, Oregon Institute of Technology, Klamath Falls, 2006, pp. 1-3.

[10] R. Bertani, Geothermal Power Generation in the World 2005-2010 Update Report, Proceeding, World Geothermal Congress 2010, Bali, Indonesia (CD-ROM).

[11] J. Lund, D. Freeston, T. Boyd, Direct Utilization of Geothermal Energy 2010 Worldwide Review, World Geothermal Congress 2010, Bali, Indonesia (CD-ROM). 